\title{
Contribution of dietary bacteria to metal accumulation in the slipper limpet
}

\author{
Jian-Wen Qiu, Pei-Yuan Qian, Wen-Xiong Wang* \\ Department of Biology, The Hong Kong University of Science and Technology (HKUST), Clear Water Bay, Kowloon, \\ Hong Kong, PR China
}

\begin{abstract}
Recent studies have shown that dietary ingestion can be an important source for metal accumulation in aquatic animals. Whether bacteria can contribute significantly to the overall metal accumulation in these animals remains little known. In this study, we used the kinetic modeling approach to examine the relative contribution of the aqueous phase, bacteria, and phytoplankton, as sources for $\mathrm{Cd}, \mathrm{Cr}$, and $\mathrm{Zn}$ accumulation by the slipper limpet Crepidula onyx, a suspension feeder that can capture bacteria efficiently. Metal uptake rate constants measured in C. onyx were 0.200 , 1.232, and $1.294 \mathrm{l} \mathrm{g}^{-1} \mathrm{~d}^{-1}$ for $\mathrm{Cd}, \mathrm{Cr}$, and $\mathrm{Zn}$, respectively. The assimilation efficiency $(A E)$ of metals from ingested phytoplankton (11 to $44 \%$ for $\mathrm{Cd}$, and 31 to $41 \%$ for $\mathrm{Zn}$ ) was comparable to AEs of metals from ingested bacteria ( 21 to $42 \%$ for $\mathrm{Cd}$, 35 to $47 \%$ for $\mathrm{Zn}$ ), whereas the $A E \mathrm{~s}$ of $\mathrm{Cr}$ from ingested phytoplankton (10 to $22 \%$ ) were lower than from ingested bacteria (44 to $59 \%$ ). The $A E$ s of $\mathrm{Cr}$ from different phytoplankton and bacterial diets were related to its distribution in the cytoplasm of cells and its passage time across the animal's guts. The limpets filtered the bacteria at rates $\left(17 \mathrm{l} \mathrm{h}^{-1} \mathrm{~g}^{-1}\right)$ 1.3 to $1.9 \times$ lower than the filtration rate on different phytoplankton diets $\left(22\right.$ to $\left.33 \mathrm{l} \mathrm{h}^{-1} \mathrm{~g}^{-1}\right)$. The estimated average bioconcentration factors of metals by 2 bacterial strains were 2 to $6 \times 10^{5}$ for Cd, 1 to $7 \times 10^{5}$ for $\mathrm{Cr}$, and 1.5 to $7 \times 10^{5}$ for $\mathrm{Zn}$. The kinetic model predicted that uptake from dietary phase dominated metal accumulation in the slipper limpets $(87 \%$ for $\mathrm{Cd}, 72 \%$ for $\mathrm{Cr}$, and $83 \%$ for $\mathrm{Zn}$ ). Ingestion of bacteria contributed $23 \%$ for $\mathrm{Cd}, 27 \%$ for $\mathrm{Cr}$, and $17 \%$ for $\mathrm{Zn}$ accumulation in the limpets under typical conditions for the limpets. Our study therefore highlights bacteria as a potentially important source of metal accumulation in this filter-feeding mollusc.
\end{abstract}

KEY WORDS: Limpets $\cdot$ Metals $\cdot$ Bacteria $\cdot$ Trophic transfer

\section{INTRODUCTION}

In aquatic ecosystems, bacteria production amounts up to $30 \%$ of the total primary production (Fenchel 1987). Bacteria are an important component of the microbial loop (Azam et al. 1983). A variety of aquatic animals, common or dominant in their communities, have been shown to effectively capture bacteria in addition to other planktonic food (e.g., acleractinian coral, Bak et al. 1998; reef sponges, Reiswig 1974, Pile 1997; polychaete larvae and juveniles, Gosselin \& Qian 1997, 2000; mussels, Seiderer \& Newell 1985, Langdon \& Newell 1990, Kreeger \& Newell 1996;

${ }^{*}$ Corresponding author. E-mail: wwang@ust.hk clams, Decho \& Luoma 1991, 1996; oyster larvae and adults, Langdon \& Newell 1990, Douillet 1993, Douillet \& Langdon 1993; asteroid larvae, Rivkin et al. 1986; and ascidians, Bak et al. 1998). These studies have pointed out the significance of bacteria as a carbon source for the animal nutrition. However, no study has considered the potential contribution of bacteria as source for metal accumulation in these herbivores. There is essentially no knowledge of the quantitative significance of bacteria as potential contributors to metal accumulation in suspension-feeding macroinvertebrates, although several studies have emphasized the transfer of metals in the microbial loop (e.g., from bacteria to flagellates and protozoans, Barbeau et al. 1996, Twiss et al. 1996). 
Dietary exposure has been increasingly recognized as a major source for metal accumulation in many aquatic invertebrates (Wang \& Fisher 1999a). Recent laboratory and field studies have shown that they acquire a significant proportion of metals from their ingested food, rather than solely from the ambient water (Reinfelder et al. 1998, Munger et al. 1999, Wang \& Fisher 1999a). Both experimental manipulation and kinetic modeling approaches have generally been used to delineate the exposure pathways of metals in these aquatic invertebrates (Wang \& Fisher 1999a). The kinetic modeling approach requires the measurement of physiological parameters including ingestion, assimilation, depuration, and growth. The accuracy of such modeling depends on how representative the selected food items are of the natural diet, because the organism's physiological processes vary dramatically with food type (Reinfelder et al. 1998). Most previous studies were concerned with phytoplankton diets as food sources for metal uptake by marine herbivores. Very few studies have considered the uptake of dietary bacteria by aquatic macroinvertebrates (e.g., Decho \& Luoma 1991, 1996, Roditi \& Fisher 1999).

The slipper limpet Crepidula onyx Sowerby is a mollusc common in Hong Kong waters. Its maximum density can reach up to 900 limpets $\mathrm{m}^{-2}$ in the sublittoral zone (Huang et al. 1984). This species has been found to effectively remove bacteria from the water column, suggesting that bacteria may be a potential food source for the mollucs (J.-W.Q. pers. obs.). This study attempted to quantify the relative contribution of the aqueous phase, bacteria, and phytoplankton to the total metal accumulation by this species. The objectives are to better understand the pathways through which the limpets acquire metals and the physiological processes responsible for metal intake. The results will be helpful for understanding the role of bacteria in transferring trace metals through the food web and whether it is appropriate to ignore bacteria when identifying the sources and predicting the fate of trace metals in aquatic ecosystems.

\section{MATERIALS AND METHODS}

Slipper limpets. Adult Crepidula onyx were collected from the pilings at the ferry terminal of Tsim Sha Tsui, Hong Kong, at low tide. Upon arrival in the laboratory, the adults were allowed to attach onto glass plates $(15 \times 15 \mathrm{~cm})$ and maintained in a $30 \mathrm{l}$ aquarium and fed with algal food Isochrysis galbana. Individual limpets carrying brooding pouches were transferred into beakers containing 21 of seawater where veliger larvae were released. At $25^{\circ} \mathrm{C}$ and a food concentration of $2 \times 10^{5}$ cells ml $\mathrm{m}^{-1}$ (I. galbana), the larvae devel- oped to the competent stage in $10 \mathrm{~d}$, settled and metamorphosed into juveniles. Under the same culture conditions, juveniles reached 1.2 to $1.5 \mathrm{~cm}$ shell length within 2 to 3 mo and were used in the experiments. All experimental seawater was collected from Clear Water Bay, Hong Kong (28 psu).

Metals. Three metals (Cd, Cr, and $\mathrm{Zn})$, which are of major environmental concern in Hong Kong waters (Blackmore 1998), were examined in this study. Among the 3 metals, $\mathrm{Zn}$ is essential whereas $\mathrm{Cd}$ and $\mathrm{Cr}$ can be toxic to aquatic organisms at relatively low concentrations. A radiotracer technique using ${ }^{109} \mathrm{Cd}$, ${ }^{51} \mathrm{Cr}$, and ${ }^{65} \mathrm{Zn}$ was employed to study the accumulation of $\mathrm{Cd}, \mathrm{Cr}$, and $\mathrm{Zn}$, respectively. Radioactivity of ${ }^{109} \mathrm{Cd}$, ${ }^{51} \mathrm{Cr}(\mathrm{III})$, and ${ }^{65} \mathrm{Zn}$ in the samples was measured using a Wallac $1480 \mathrm{NaI}(\mathrm{T} 1)$ gamma detector (Turku, Finland). The gamma emissions of ${ }^{109} \mathrm{Cd},{ }^{51} \mathrm{Cr}$, and ${ }^{65} \mathrm{Zn}$ were detected at $88,320,1115 \mathrm{keV}$, respectively. The radioactivity was calibrated for radioactive decay, spillover, and counting efficiency using appropriate standards. Counting time was adjusted to yield a propagated counting error $<5 \%$.

Uptake of metals from the dissolved phase. Metal uptake was determined at different concentrations $(4.5,17.8,89.3$, and $446 \mathrm{nM}$ for $\mathrm{Cd}, 9.6,38.5,192$, and $962 \mathrm{nM}$ for Cr(III), and 15.4, 76.9, 308, and $1538 \mathrm{nM}$ for $\mathrm{Zn})$. The lowest concentrations used in the experiments were about 5 to $50 \times$ higher than the lowest metal concentrations recorded in Hong Kong coastal waters (Wang \& Dei 1999a). A radioisotope of each metal was added as a tracer and was equilibrated with stable metals for $12 \mathrm{~h}$ prior to the experiments. Radioisotope addition was $17.5 \mathrm{kBq} \mathrm{l}^{-1}$ for each isotope. Individual limpets were placed in $100 \mathrm{ml}$ of $0.2 \mu \mathrm{m}$ filtered seawater containing both isotopes and stable metals. Eight replicate individuals were used at each concentration treatment. At time intervals of 2, 4, 6 and $8 \mathrm{~h}$, the limpets were removed from the radioactive media, rinsed with non-radioactive seawater, and their radioactivity was immediately counted (for $2 \mathrm{~min}$ ). Following counting, the limpets were returned to the exposure beakers. At the end of experiment $(8 \mathrm{~h})$, they were dissected and the dry weights of their tissues and shells were measured following drying at $80^{\circ} \mathrm{C}$ for $1 \mathrm{~d}$.

Assimilation of metals from ingested food. The assimilation by the limpets of metals from ingested food including different algal diets and bacteria was quantified. Four algal species (diatom Thalassiosira pseudonana, green alga Chlorella autotrophica, prasinophyte Tetraselmis levis, and dinoflagellate Prorocentrum minimum) and 2 heterotrophic bacteria strains were used as food for the limpets (Table 1). The algae were obtained from the Provasoli-Guillard Center for the Culture of Marine Phytoplankton (Maine, USA), while the bacteria were isolated from Port 
Table 1. Crepidula onyx. Phytoplankton and bacteria used as diets for the measurement of metal assimilation efficiency in the slipper limpets. Data in parentheses are the standard deviations of 10 replicate measurements. Bacteria strain numbers correspond to the strains and properties described in Gosselin \& Qian (1997)

\begin{tabular}{|lcccc|}
\hline Food item & Phylum & Cell shape & $\begin{array}{c}\text { Cell dry weight } \\
\left(\text { pg cell }{ }^{-1}\right)\end{array}$ & $\begin{array}{c}\text { Cell dimensions } \\
(\mu \mathrm{m})\end{array}$ \\
\hline Prorocentrum minimum & Pyrrohophyta & Oval & 250 & $17.8(0.6) \times 20.1(1.1)$ \\
Tetraselmis levis & Chlorophyta & Oval & $8.2(1.3) \times 14.0(1.2)$ \\
Thalassiosira pseudonana & Chrysophyta & Cylinder & 144 & $5.0(0.4) \times 6.5(1.0)$ \\
Chlorella autotrophica & Chlorophyta & Sphere & 24 & $3.9(0.3)$ \\
Bacteria strain M11 & Schizomycophyta & Rod & 0.019 & $0.8(0.3) \times 1.5(0.2)$ \\
Bacteria strain M4 & Schizomycophyta & Cocci & 0.015 & $1.22(0.15)$ \\
& & & & \\
\hline
\end{tabular}

Shelter, Hong Kong. The algae were cultured using f/2 enriched seawater (Guillard 1975 ) at $18^{\circ} \mathrm{C}$ and $30 \mathrm{psu}$. The bacteria were cultured using Nutrient Broth No. 2 (Oxoid Inc., Hampshire, UK) in the dark at $30^{\circ} \mathrm{C}$. The dry weights of algae and bacteria were determined after filtering the cells onto pre-combusted GF/F membranes, rinsing with $0.5 \mathrm{M}$ ammonia formate, and drying at $60^{\circ} \mathrm{C}$ for $24 \mathrm{~h}$. Algal cells in the exponential growth phase were filtered and re-suspended into $150 \mathrm{ml}$ of $0.22 \mu \mathrm{m}$ filtered seawater enriched with the $\mathrm{f} / 2$ levels of $\mathrm{N}, \mathrm{P}, \mathrm{Si}$, and vitamins, and f/20 levels of trace metals minus EDTA, Cu, and Zn (Wang \& Fisher 1996). The initial cell density ranged from 10000 to 50000 cells $\mathrm{ml}^{-1}$. Radioisotopes $\left(30 \mathrm{nM}{ }^{109} \mathrm{Cd}, 0.6 \mathrm{nM}\right.$ ${ }^{51} \mathrm{Cr}$, and $30 \mathrm{nM}{ }^{65} \mathrm{Zn}$ ) were added into the medium to co-incubate with the algae. The cells were cultured for 3 to $5 \mathrm{~d}$ to allow for several divisions. The cells considered uniformly radiolabeled were collected onto 1 to $3 \mu \mathrm{m}$ polycarbonate membranes and resuspended into $0.22 \mu \mathrm{m}$ filtered seawater. This procedure was repeated twice to remove the radioisotopes weakly bound onto the cell surfaces. After cell density determination, the algae were added into the feeding beakers at $4.8 \times 10^{4}$ cells ml ${ }^{-1}$ for $P$. minimum, $8.3 \times 10^{4}$ cells $\mathrm{ml}^{-1}$ for $T$. levis, $5 \times 10^{5}$ cells $\mathrm{ml}^{-1}$ for $T$. pseudonana, and $8 \times 10^{5}$ cells $\mathrm{ml}^{-1}$ for $C$. autotrophica before adding the slipper limpets. The cell biomass in the feeding beakers was comparable among the different algal diet treatments. Metal distribution in the algal cytoplasm and cell walls was determined by the method described by Fisher et al. (1983) and Reinfelder \& Fisher (1991).

Bacteria were cultured using Nutrient Broth No. 2 (Oxoid Inc.) in the dark for $2 \mathrm{~d}$ at $30^{\circ} \mathrm{C}$ and $28 \mathrm{psu}$ in a shaking table and were harvested by centrifugation. Since our preliminary experiments showed that, in the presence of the broth, bacteria cells were not able to take up sufficient radioactive metals for experimentation, radiolabeling was conducted in suspension after the harvest. Bacterial concentrations were determined by fluorescence microscopic counting following staining the cells with 4', 6'-diamidino-2-phenylin-dole (DAPI) (Porter \& Feig 1980). After $1 \mathrm{~d}$ of radiolabeling (with initial cell densities of $8.7 \times 10^{6}$ cells ml $^{-1}$ for strain M11 and $1.6 \times 10^{7}$ cells $\mathrm{ml}^{-1}$ for strain M4), the cells were collected onto $0.7 \mu \mathrm{m}$ polycarbonate membranes and re-suspended in $0.22 \mu \mathrm{m}$ filtered seawater. This procedure was repeated to remove weakly bounded radioisotopes. The bacteria were then diluted to $4.8 \times$ $10^{6}$ cells ml ${ }^{-1}$ for strain M11 and $6.5 \times 10^{6}$ cells ml $^{-1}$ for strain M4 before being fed to the slipper limpets. To determine metal distribution in the cytoplasm and cell surface of each strain, the cells were collected by filtration, rinsed with EDTA and re-suspended in seawater. The samples were frozen at $-20^{\circ} \mathrm{C}$ for $2 \mathrm{~d}$, thawed, ultrasonicated for $10 \mathrm{~min}$, and centrifuged at $10000 \mathrm{rpm}$ for $10 \mathrm{~min}$ to separate the supernatant and pellets before the radioactivity measurement.

A pulse-chase feeding technique was employed to determine the metal assimilation efficiency for each algal species and the bacterial strain (Wang \& Fisher 1999b). There were 5 to 6 replicate exposure beakers per treatment, each with 1 slipper limpet. After 0.5 to $1 \mathrm{~h}$ feeding on radiolabeled algae or bacteria, the slipper limpets were retrieved, rinsed with seawater, and their radioactivity was immediately determined. The slipper limpets were then allowed to depurate for $46 \mathrm{~h}$ in the presence of non-radiolabelled Isochrysis galbana. During the depuration period, the radioactivity of the juveniles and their egested fecal pellets were determined at time intervals. Seawater and food were renewed each time the animals were taken for radioassay.

Assimilation efficiency $(A E)$ was calculated as the $y$ intercept of the linear regression between the ln \% of the metal retained in the animal and the time of depuration (during the slower phase of depuration, 21 to $46 \mathrm{~h})$ :

$$
\% A=A_{\mathrm{o}} \mathrm{e}^{-\mathrm{k} t}
$$

where, $\% A$ is the percentage of radioactivity retained in slipper limpets at time $t, A_{\mathrm{o}}$ is the $y$-intercept of the 
percentage of radioactivity retained in the slipper limpets, which is defined as the $A E$ of the metals, $\mathrm{k}$ is the depuration rate constant, and $t$ is time of depuration. This model assumes a 2-compartment depuration pattern for ingested metal, with the first compartment representing the digestive and assimilative process, and the second compartment representing the physiological turnover of metals.

Filtration rate. Filtration rate of the limpets was determined by monitoring the decrease of algal or bacterial density over time using established methods (Widdows 1985, Wang \& Dei 1999b). The algal cell density was determined using a Coulter Multisizer II (Coulter Co., FL, USA). The concentration of bacteria was determined by fluorescence microscopy after staining the cells with DAPI. For each food item, there were 3 replicates and 3 controls. Individual slipper limpets were placed in $500 \mathrm{ml}$ of filtered seawater containing the algal or bacterial suspension. The control contained the same concentration of algae or bacteria without the slipper limpet. The water was gently mixed by a magnetic stirrer. Algal and bacterial concentrations were adjusted such that the slipper limpets had access to similar algal and bacterial biomass at the beginning of the experiment, which was run for $2 \mathrm{~h}$. Triplicates of $15 \mathrm{ml}$ of seawater were taken for cell density determination at the beginning and at the end of the exposure. The filtration rate was calculated from the exponential decrease in particle concentration during the $2 \mathrm{~h}$ feeding period, after calibrating for the change in cell density in the control treatments.

Kinetic separation of metal uptake pathways. According to a bioenergetic-based kinetic model (Thomann 1981, Landrum et al. 1992, Wang et al. 1996), metal accumulation in the organism can be described as:

$$
\mathrm{d} C / \mathrm{d} t=\mathrm{k}_{\mathrm{u}} C_{\mathrm{w}}+A E \times I R \times C_{\mathrm{f}}-\mathrm{k}_{\mathrm{e}} C
$$

where $C$ is the metal concentration in the animal at time $t, \mathrm{k}_{\mathrm{u}}$ is the uptake rate constant from the dissolved phase, $C_{\mathrm{w}}$ is the metal concentration in the dissolved phase, $A E$ is the metal assimilation efficiency from ingested food, $I R$ is the ingestion rate, $C_{\mathrm{f}}$ is the metal concentration in the food source, $k_{e}$ is the organism's metal efflux rate constant. Influx rate from the dietary phase $\left(A E \times I R \times C_{\mathrm{f}}\right)$ can be further separated into 2 components, namely, the seston (s) (e.g., phytoplankton) and the bacteria (b):

$\mathrm{d} C / \mathrm{d} t=\mathrm{k}_{\mathrm{u}} C_{\mathrm{w}}+A E_{\mathrm{b}} \times I R_{\mathrm{b}} \times C_{\mathrm{fb}}+A E_{\mathrm{s}} \times I R_{\mathrm{s}} \times C_{\mathrm{fs}}-\mathrm{k}_{\mathrm{e}} C$

In the slipper limpets, the relative importance of dissolved uptake versus seston ingestion and bacteria ingestion can be estimated by comparing the relative influx rate of metal from each source. Thus, the ratio of metal uptake from dissolved phase $\left(R_{\mathrm{w}}\right)$, seston in- gestion $\left(R_{\mathrm{s}}\right)$, and ingestion of bacteria $\left(R_{\mathrm{b}}\right)$, can be calculated as:

$$
\begin{gathered}
R_{\mathrm{w}}=\mathrm{k}_{\mathrm{u}} C_{\mathrm{w}} /\left(\mathrm{k}_{\mathrm{u}} C_{\mathrm{w}}+A E_{\mathrm{b}} \times I R_{\mathrm{b}} \times C_{\mathrm{fb}}+A E_{\mathrm{s}} \times I R_{\mathrm{s}} \times C_{\mathrm{fs}}\right) \\
R_{\mathrm{s}}=\left(A E_{\mathrm{s}} \times I R_{\mathrm{s}} \times C_{\mathrm{fs}}\right) /\left(\mathrm{k}_{\mathrm{u}} C_{\mathrm{w}}+A E_{\mathrm{b}} \times I R_{\mathrm{b}} \times\right. \\
\left.C_{\mathrm{fb}}+A E_{\mathrm{s}} \times I R_{\mathrm{s}} \times C_{\mathrm{fs}}\right) \\
R_{\mathrm{b}}=\left(A E_{\mathrm{b}} \times I R_{\mathrm{b}} \times C_{\mathrm{fb}}\right) /\left(\mathrm{k}_{\mathrm{u}} C_{\mathrm{w}}+A E_{\mathrm{b}} \times I R_{\mathrm{b}} \times\right. \\
\left.C_{\mathrm{fb}}+A E_{\mathrm{s}} \times I R_{\mathrm{s}} \times C_{\mathrm{fs}}\right)
\end{gathered}
$$

Assuming that the metal concentration in ingested seston $\left(C_{\mathrm{fs}}\right)$ and in bacteria $\left(C_{\mathrm{fb}}\right)$ can be predicted based on measurements of the metal partitioning coefficients in seston $\left(K_{\mathrm{ds}}\right)$ and in bacteria $\left(K_{\mathrm{db}}\right)$ :

$$
\begin{aligned}
& C_{\mathrm{fb}}=K_{\mathrm{db}} \times C_{\mathrm{w}} \\
& C_{\mathrm{fs}}=K_{\mathrm{ds}} \times C_{\mathrm{w}}
\end{aligned}
$$

Thus, Eqs (3) \& (4) can be rewritten as:

$$
\begin{gathered}
R_{\mathrm{w}}=\mathrm{k}_{\mathrm{u}} /\left(\mathrm{k}_{\mathrm{u}}+A E_{\mathrm{b}} \times I R_{\mathrm{b}} \times K_{\mathrm{db}}+A E_{\mathrm{p}} \times I R_{\mathrm{p}} \times K_{\mathrm{ds}}\right) \\
R_{\mathrm{b}}=\left(A E_{\mathrm{b}} \times I R_{\mathrm{b}} \times K_{\mathrm{db}}\right) /\left(\mathrm{k}_{\mathrm{u}}+A E_{\mathrm{b}} \times I R_{\mathrm{b}} \times\right. \\
\left.K_{\mathrm{db}}+A E_{\mathrm{p}} \times I R_{\mathrm{p}} \times K_{\mathrm{ds}}\right) \\
R_{\mathrm{s}}=\left(A E_{\mathrm{s}} \times I R_{\mathrm{s}} \times K_{\mathrm{ds}}\right) /\left(\mathrm{k}_{\mathrm{u}}+A E_{\mathrm{b}} \times I R_{\mathrm{b}} \times\right. \\
\left.K_{\mathrm{db}}+A E_{\mathrm{p}} \times I R_{\mathrm{p}} \times K_{\mathrm{ds}}\right)
\end{gathered}
$$

\section{RESULTS}

\section{Metal uptake from the dissolved phase}

Uptake of $\mathrm{Cd}, \mathrm{Cr}$, and $\mathrm{Zn}$ from the dissolved phase by whole individual limpet followed a linear pattern over the exposure time (data not shown). Although the tissue accounted for only $11.2 \pm 0.2 \%$ (mean $\pm \mathrm{SD}, \mathrm{n}=$ 32 ) of the total body weight, $>75 \%$ of metals were associated with the tissues during the uptake period (Cd: $76.1 \pm 15.0 \%, C r: 77.1 \pm 22.8 \%, Z n: 78.2 \pm 9.8 \%$ ). It was therefore not possible to calculate the influx rate of metals into the soft tissues based on the measurements of radioactivity in whole individual limpets. We calculated the influx rate of metals into the soft tissues based on the measurements of radioactivity in the soft tissues at the end of the exposure. With this method, it was assumed that the rate of uptake by soft tissues was constant over time. A log-log linear relationship between metal influx rate into the limpet tissues and metal concentration in the dissolved phase was evident for the 3 metals (Fig. 1). The dissolved uptake constant $\left(\mathrm{k}_{\mathrm{u}}\right)$, calculated as the slope of the linear regression, was $0.200 \mathrm{l} \mathrm{g}^{-1} \mathrm{~d}^{-1}$ for $\mathrm{Cd}, 1.232 \mathrm{l} \mathrm{g}^{-1} \mathrm{~d}^{-1}$ for $\mathrm{Cr}$, and $1.294 \mathrm{l} \mathrm{g}^{-1} \mathrm{~d}^{-1}$ for $\mathrm{Zn}$. Such calculation assumed that the power coefficient of the relationship between metal 


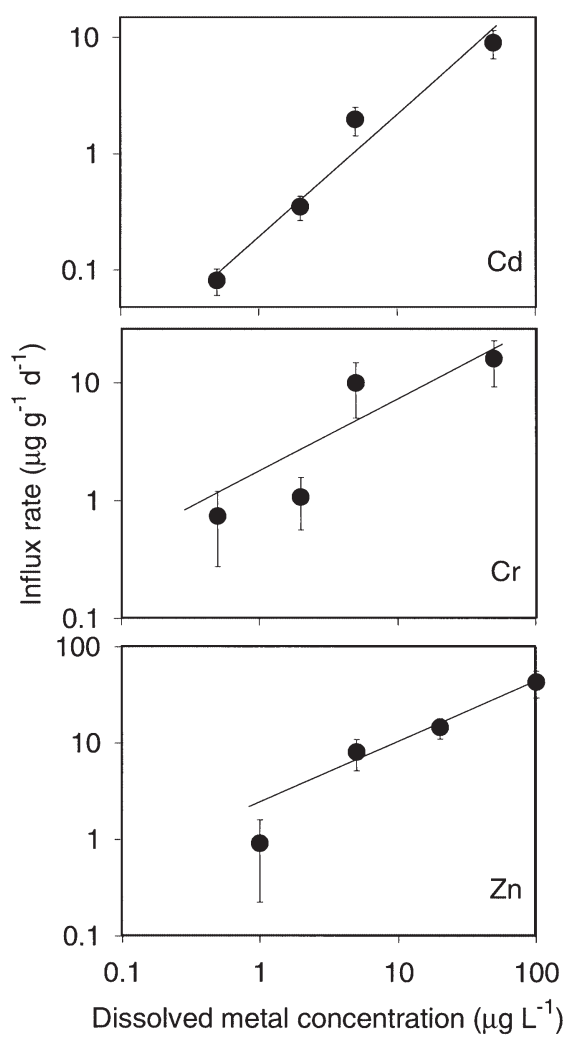

Fig. 1. Crepidula onyx. Metal influx rate $\left(I_{\mathrm{W}}\right)$ into the limpets' soft tissue as a function of metal concentration in the dissolved phase $\left(C_{\mathrm{w}}\right)$. Mean $\pm \mathrm{SD}(\mathrm{n}=8)$. Regressions describing such relationships are: for $\mathrm{Cd}: I_{\mathrm{w}}=0.200 C_{\mathrm{w}}{ }^{1.036 \pm 0.150}\left(\mathrm{r}^{2}=0.960\right)$; for $\mathrm{Cr}$ : $I_{\mathrm{w}}=1.232 C_{\mathrm{w}}^{0.723 \pm 0.244}\left(\mathrm{r}^{2}=0.815\right)$; for $\mathrm{Zn}: I_{\mathrm{w}}=$ $1.294 C_{\mathrm{W}}^{0.802 \pm 0.140}\left(\mathrm{r}^{2}=0.943\right)$

influx rate and metal concentration in the dissolved phase was close to 1 .

\section{Metal assimilation from ingested food particles}

The retention of $\mathrm{Cd}, \mathrm{Cr}$, and $\mathrm{Zn}$ in the slipper limpets following a pulse feeding is shown in Fig. 2. The pattern of metal depuration was characterized by a rapid release within the first few hours, followed by a gradual decline. We calculated the assimilation efficiencies (AEs) of the metals by regressing the natural log of the $\%$ of metal retention with time of depuration during the second phase of depuration (21 to $48 \mathrm{~h}$ ) (Table 2). There were considerable intra-elemental variations among the metal $A E$ s, ranging from 10 to $59 \%$ for $\mathrm{Cr}, 11$ to $44 \%$ for $\mathrm{Cd}$, and 31 to $47 \%$ for $\mathrm{Zn}$. For Cd, Chlorella autotrophica had the lowest $A E(11 \%)$, whereas Prorocentrum minimum had the

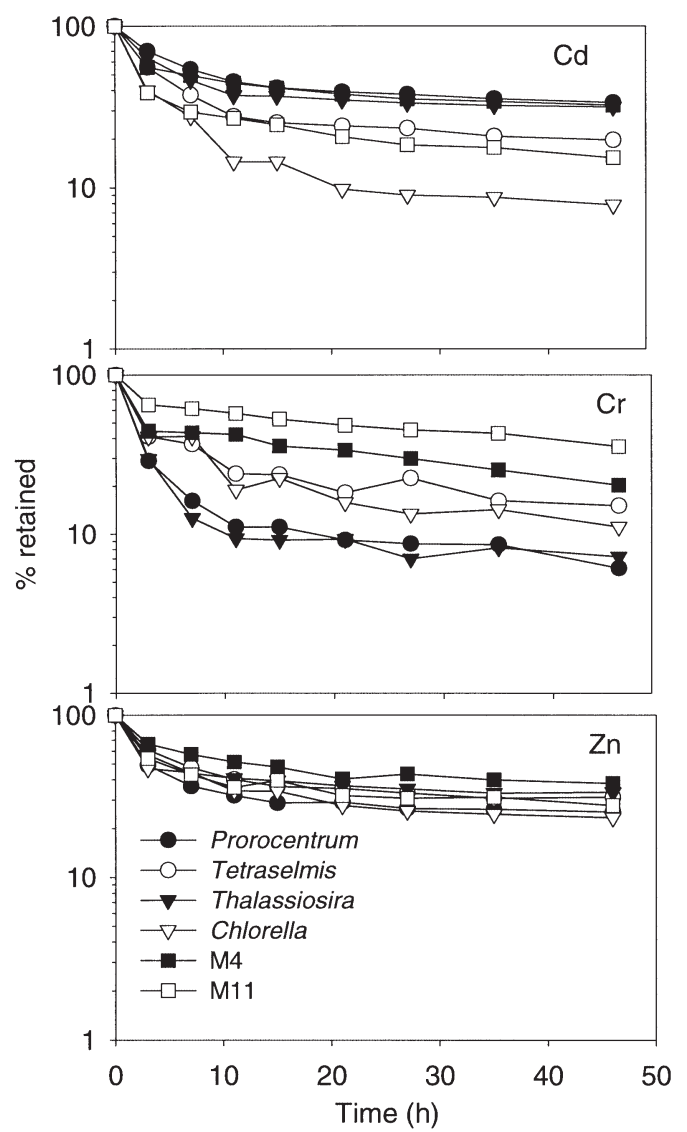

Fig. 2. Crepidula onyx. Metal retention in the limpets following a pulse feeding on different radiolabeled phytoplankton and bacteria (Strains M4 and M11). Only means are presented. The standard deviation of the calculated metal assimilation efficiency is shown in Table 2

highest $A E(44 \%)$. Difference in algal diets significantly affected the $A E$ s of $\mathrm{Cd}(\mathrm{p}<0.001,1$-way ANOVA), but not the $A E$ s of $\mathrm{Cr}$ and $\mathrm{Zn}$. The $A E$ varied by about $2 \times$ for the 2 bacterial strains tested, and the difference was significant for $\mathrm{Cd}(\mathrm{p}<0.01, t$-test) and $\mathrm{Cr}(\mathrm{p}<0.05, t$-test). For $\mathrm{Cr}$, the $A E$ s from the 2 bacteria strains (44 to $59 \%$ ) were substantially higher than those from algae (10 to $21 \%$ ). There was less variation

Table 2. Crepidula onyx. The measured assimilation efficiency (\%) of $\mathrm{Cd}$, $\mathrm{Cr}$, and $\mathrm{Zn}$ in the slipper limpets feeding on different phytoplankton and bacterial diets. Values are mean $\pm \mathrm{SD}(\mathrm{n}=5)$

\begin{tabular}{|llrl|}
\hline Food item & \multicolumn{1}{c}{$\mathrm{Cd}$} & $\mathrm{Cr}$ & $\mathrm{Zn}$ \\
\hline Prorocentrum minimum & $43.8 \pm 6.4$ & $11.9 \pm 7.2$ & $31.2 \pm 9.6$ \\
Tetraselmis levis & $28.0 \pm 11.9$ & $21.3 \pm 7.4$ & $37.8 \pm 3.9$ \\
Thalassiosira pseudonana & $37.2 \pm 7.6$ & $9.7 \pm 3.6$ & $42.4 \pm 8.0$ \\
Chlorella autotrophica & $11.3 \pm 4.5$ & $14.8 \pm 7.8$ & $30.7 \pm 20.2$ \\
Bacteria strain M11 & $20.9 \pm 1.0$ & $59.0 \pm 8.7$ & $35.3 \pm 1.7$ \\
Bacteria strain M4 & $41.6 \pm 8.0$ & $44.5 \pm 6.5$ & $46.8 \pm 8.0$ \\
\hline
\end{tabular}




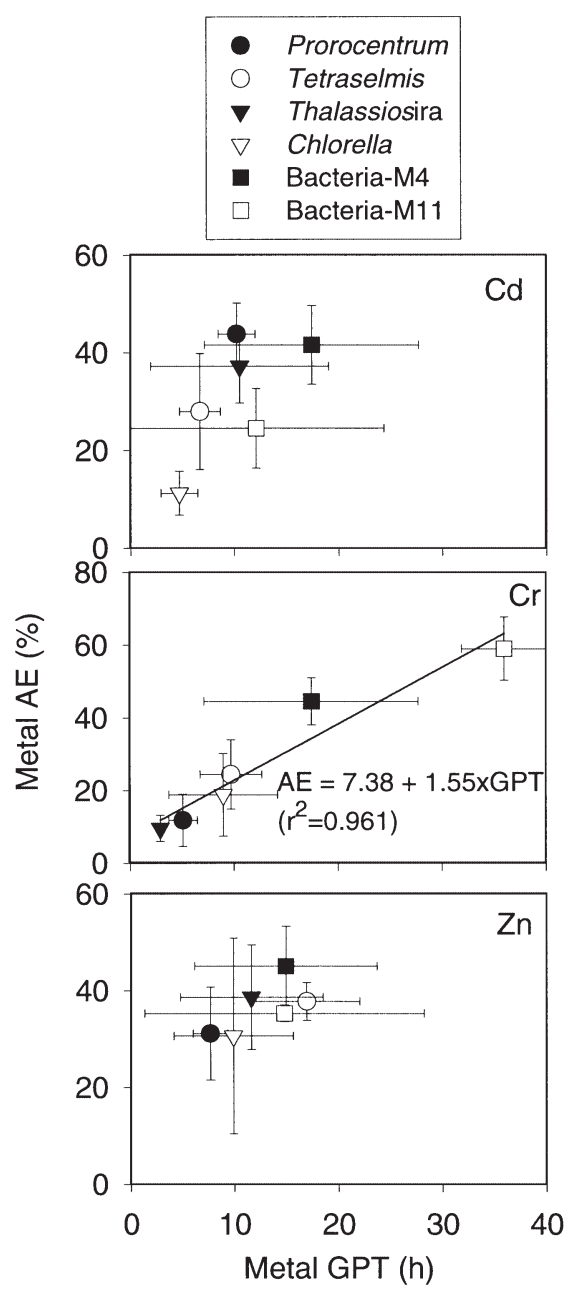

Fig. 3. Crepidula onyx. Metal assimilation efficiency $(A E)$ as a function of metal gut passage time (GPT) in the limpets feeding on different phytoplankton and bacterial (Strains M4 and M11) diets. Mean $\pm \mathrm{SD}(\mathrm{n}=5)$

of Zn $A E$ among the different diets tested than the variation of $\mathrm{Cd}$ and $\mathrm{Cr}$. Within the 4 algal diets, $A E$ was not correlated with the cell size.

Metal gut passage time (GPT) was defined as the time at which $90 \%$ of unassimilated metals were recovered in the feces, assuming a $100 \%$ recovery of feces during the $46 \mathrm{~h}$ depuration period. Overall, metal passage was completed within $35 \mathrm{~h}$ (Fig. 3). The GPTs of metals associated with bacteria exhibited greater variations than the GPTs of metals associated with the algae. For example, the GPTs of $\mathrm{Cd}$ and $\mathrm{Cr}$ for the algae were $<10 \mathrm{~h}$, whereas the GPTs of the same metals for the bacteria ranged between 12 and $36 \mathrm{~h}$. When all algae were considered, there was a significant positive correlation between the $\mathrm{Cr} A E$ and its GPT.

There were considerable differences in the metal distribution in the cytoplasm between the algae and the bacteria and among the elements (Fig. 4). Less than
$10 \%$ of $\mathrm{Cr}$ was found in the algal cytoplasm, whereas a significantly higher fraction of $\mathrm{Cr}$ was found in the bacterial cytoplasm (41 to $54 \%$ ). In general, a higher percentage of metal penetrated into the bacterial cytoplasm than into the algal cytoplasm. When all food items were considered, there was a significant positive relationship between the $A E$ and the metal distribution in the cytoplasm for $\mathrm{Cr}$, whereas no significant relationship was evident for the other 2 metals (Fig. 4).

\section{Filtration rate of the limpets}

After $2 \mathrm{~h}$ feeding, about 56 to $76 \%$ of phytoplankton and 48 to $50 \%$ of bacteria had been cleared by the

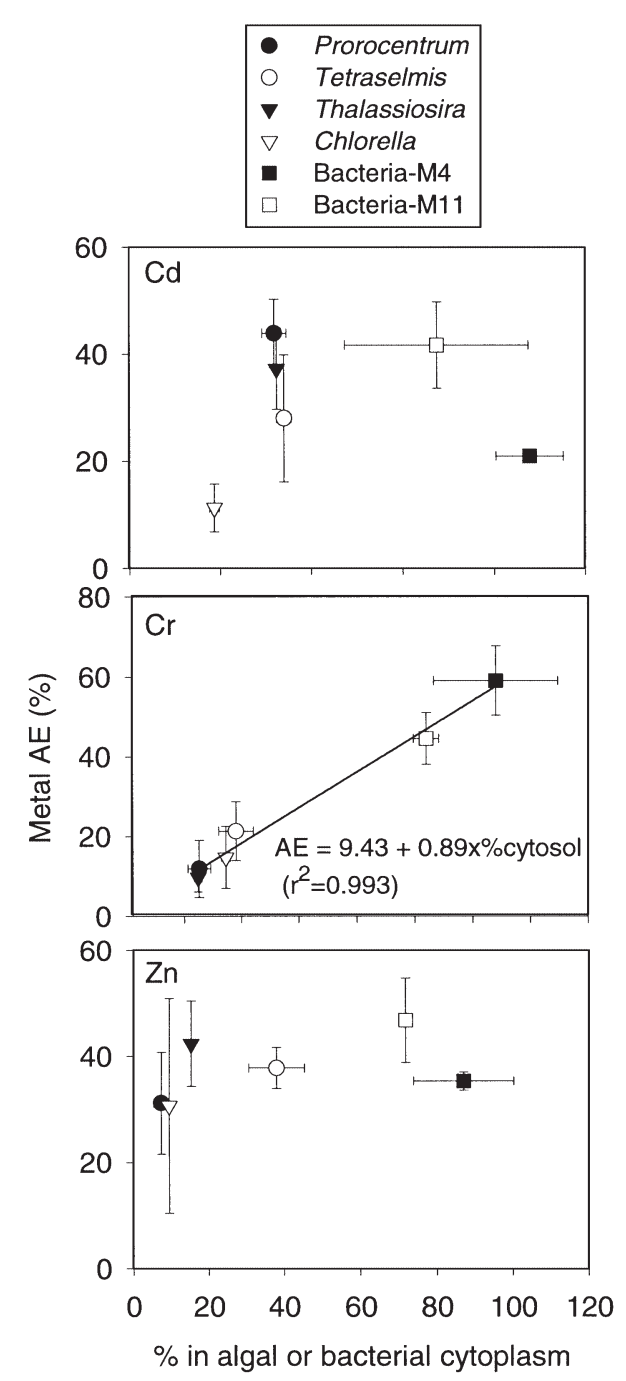

Fig. 4. Crepidula onyx. Metal assimilation efficiency $(A E)$ in the limpets feeding on different phytoplankton and bacterial diets as a function of metal distribution in the cytoplasm of phytoplankton and bacteria ( $\%$ cytosol). Mean \pm SD $(n=5)$ 


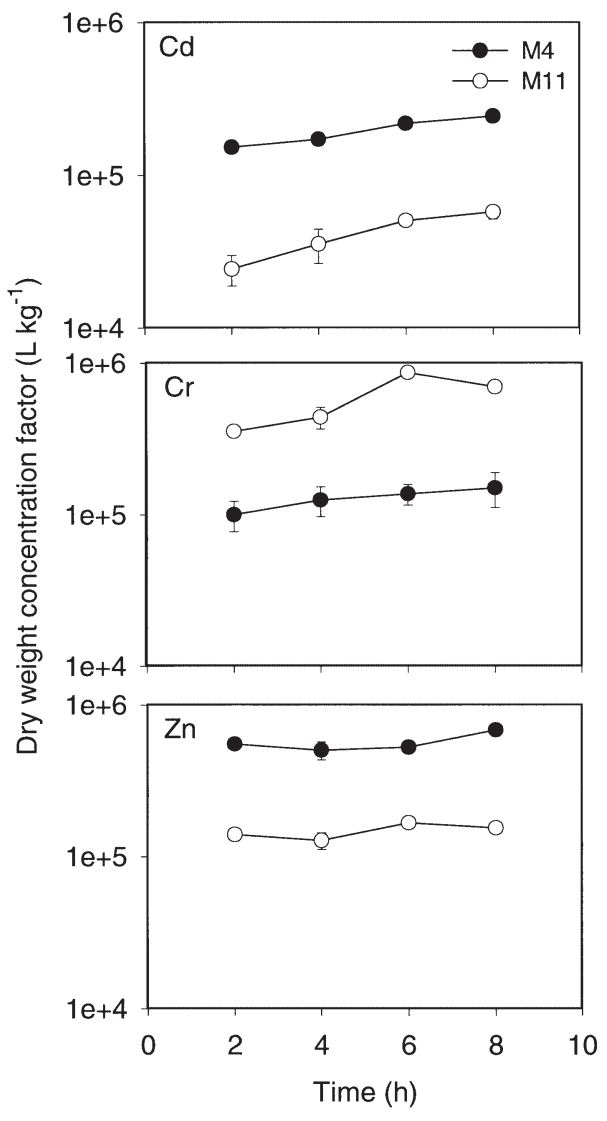

Fig. 5. Crepidula onyx. The calculated dry weight concentration factor of metals in 2 bacterial strains (M4 and M11) over $8 \mathrm{~h}$ exposure period. Mean $\pm \mathrm{SD}(\mathrm{n}=3)$ limpets. The calculated weight specific filtration rate was $21.9 \pm 2.5,26.0 \pm 0.3,32.7 \pm 9.2,30.9 \pm 3.4 \mathrm{l} \mathrm{h}^{-1} \mathrm{~g}^{-1}$ (mean $\pm \mathrm{SD}, \mathrm{n}=3$ ) for limpets feeding on Prorocentrum minimum, Tetraselmis levis, Thalassiosira pseudonana, and Chlorella autotrophica, respectively, and was $16.9 \pm 0.9$, and $17.8 \pm 3.31 \mathrm{~h}^{-1} \mathrm{~g}^{-1}$, for limpets feeding on bacteria strains M4 and M11, respectively.

\section{Uptake of metals by bacteria}

The calculated dry weight concentration factors (DCF) of metals in the 2 bacterial strains over the exposure time are shown in Fig. 5. Following the initial accumulation $(2 \mathrm{~h})$, there was a small increase in $\mathrm{Cd}$ and $\mathrm{Cr}$ accumulation by the bacteria, whereas bacteria did not show appreciable accumulation of $\mathrm{Zn}$ following the initial sorption. The calculated DCFs after $8 \mathrm{~h}$ of incubation in the M4 strain were $2.4 \times 10^{5}$ for $\mathrm{Cd}, 1.5 \times$ $10^{5}$ for $\mathrm{Cr}$, and $6.8 \times 10^{5}$ for $\mathrm{Zn}$, and in the M11 strain were $5.7 \times 10^{4}$ for $\mathrm{Cd}, 7.0 \times 10^{5}$ for $\mathrm{Cr}$, and $1.5 \times 10^{5}$ for $\mathrm{Zn}$. Accumulation of $\mathrm{Cd}$ and $\mathrm{Zn}$ by the M4 strains was 4.2 to $4.4 \times$ higher than the accumulation by the M11 strain, whereas the accumulation of Cr by the M11 strain was $4.6 \times$ higher than by the M4 strain.

\section{Kinetic separation of metal uptake pathways}

Parameters required in the kinetic model include $A E, \mathrm{k}_{\mathrm{u}}, I R$, and $K_{\mathrm{d}} . A E$ and $\mathrm{k}_{\mathrm{u}}$ were determined in this study (Table 3 ). The mean $K_{\mathrm{d}}$ values for phytoplankton were taken from Fisher \& Reinfelder (1995), whereas

Table 3. Crepidula onyx. Mean numeric values of metal physiological and geochemical parameters used in the kinetic modeling of metal uptake from different sources. Numbers in parentheses reflect the likely variability of each parameter. $\mathrm{k}_{\mathrm{u}}$ : uptake rate constant from the dissolved phase; $A E$ : assimilation efficiency; $K_{\mathrm{d}}$ : partition coefficient of metals in food particles; IR: ingestion rate of the limpets; \% uptake: the predicted percentage of metal uptake from each source

\begin{tabular}{|c|c|c|c|c|c|}
\hline Food/Metal & $\underset{\left(\mathrm{g} \mathrm{g}^{-1} \mathrm{~d}^{-1}\right)}{\mathrm{k}_{\mathrm{u}}}$ & $A E(\%)$ & $K_{\mathrm{d}}\left(\mathrm{l} \mathrm{kg}^{-1}\right)$ & $I R\left(\mathrm{~g} \mathrm{~g}^{-1} \mathrm{~d}^{-1}\right)$ & $\%$ uptake \\
\hline \multicolumn{6}{|l|}{ Phytoplankton } \\
\hline $\mathrm{Cd}$ & 0.200 & $30(10-45)$ & $\begin{array}{c}5000 \\
(1000-10000)\end{array}$ & 0.67 & 64 \\
\hline $\mathrm{Cr}$ & 1.232 & $15(10-20)$ & $\begin{array}{c}20000 \\
(10000-100000)\end{array}$ & 0.67 & 45 \\
\hline $\mathrm{Zn}$ & 1.294 & $35(30-45)$ & $\begin{array}{c}20000 \\
(10000-100000)\end{array}$ & 0.67 & 63 \\
\hline \multicolumn{6}{|l|}{ Bacteria } \\
\hline $\mathrm{Cd}$ & 0.200 & $30(20-40)$ & $\begin{array}{c}100000 \\
(30000-300000)\end{array}$ & 0.0061 & 23 \\
\hline $\mathrm{Cr}$ & 1.232 & $50(45-60)$ & $\begin{array}{c}200000 \\
(100000-800000)\end{array}$ & 0.0061 & 27 \\
\hline $\mathrm{Zn}$ & 1.294 & $40(35-50)$ & $\begin{array}{c}300000 \\
(100000-700000)\end{array}$ & 0.0061 & 19 \\
\hline
\end{tabular}


those of bacteria were measured in this study. The mean filtration rates of Crepidula onyx were $28 \mathrm{l} \mathrm{h}^{-1}$ $\mathrm{g}^{-1}$ and $17 \mathrm{l} \mathrm{h}^{-1} \mathrm{~g}^{-1}$ when the animals fed on algal cells and bacteria, respectively. The typical bacterial concentration in Hong Kong waters is approximately 1 to $3 \times 10^{6}$ cells $\mathrm{ml}^{-1}$ (Gosselin \& Qian 1997), and the typical seston concentration is about $1 \mathrm{mg} \mathrm{l}^{-1}$ (Chiu et al. 1994). In modeling, we therefore used $2 \times 10^{6}$ cells $\mathrm{ml}^{-1}$ and $1 \mathrm{mg} \mathrm{l}^{-1}$ as representative bacterial and seston concentrations for Hong Kong waters. The calculated ingestion rate of slipper limpets on bacteria was therefore $12 \mathrm{mg} \mathrm{g}^{-1} \mathrm{~d}^{-1}$, assuming a dry weight of $0.015 \mathrm{pg}$ cell $^{-1}$ for bacteria (Table 1). The calculated ingestion rate of these limpets on seston was about $0.67 \mathrm{~g} \mathrm{~g}^{-1} \mathrm{~d}^{-1}$.

Using the mean numeric value of each physiological and geochemical parameter, the model shows that uptake from the dissolved phase accounts for only 13, 28 , and $17 \%$ of $\mathrm{Cd}, \mathrm{Cr}$, and $\mathrm{Zn}$ accumulation in the slipper limpets, whereas the particulate phase accounts for 87,72 , and $83 \%$ of $\mathrm{Cd}, \mathrm{Cr}$, and $\mathrm{Zn}$ accumulation (Table 3). When the particle ingestion was further divided into bacterial and seston components, a larger fraction of metals is derived from ingestion of natural seston $(64 \%$ for $\mathrm{Cd}, 45 \%$ for $\mathrm{Cr}$, and $63 \%$ for $\mathrm{Zn})$. However, a measurable fraction of metals is indeed derived from the ingestion of bacteria. For example, the model predicts that $23 \%$ of $\mathrm{Cd}, 27 \%$ of $\mathrm{Cr}$, and $17 \%$ of $\mathrm{Zn}$ in the slipper limpets is derived from bacteria due to their efficient filtration of bacteria.

\section{DISCUSSION}

In this study, metal uptake from the dissolved phase by the slipper limpet Crepidula onyx proceeded linearly over time, consistent with many previous studies of aquatic invertebrates (George \& Coombs 1977, Bjerregaard et al. 1985, Wang \& Dei 1999b). Because there was substantial accumulation of metals in the shells, measurements of radioactivity in the soft tissues after $8 \mathrm{~h}$ of exposure were used to calculate the metal influx rate into the soft tissues, assuming that metal accumulation by the soft tissues also proceeded linearly over time of exposure. The uptake rate constant was then calculated by regressing the log of the metal influx rate against the metal concentration in the dissolved phase. The calculated uptake rate constants $(0.200,1.232$, and $1.294 \mathrm{l} \mathrm{g}^{-1} \mathrm{~d}^{-1}$ for $\mathrm{Cd}, \mathrm{Cr}$, and $\mathrm{Zn}$, respectively) were generally comparable to the metal uptake rate constants measured with suspension-feeding mussels such as Mytilus edulis, with the exception of $\mathrm{Cr}$ (Wang et al. 1996). The uptake of Cr(III) by the slipper limpets was much higher than its uptake by other suspensionfeeding invertebrates. For example, the uptake rate constant of $\mathrm{Cr}(\mathrm{III})$ measured in the mussel $M$. edulis was about $0.034 \mathrm{l} \mathrm{g}^{-1} \mathrm{~d}^{-1}$ (Wang et al. 1997). This study did not measure the uptake of $\mathrm{Cr}(\mathrm{VI})$, which generally has a higher uptake rate than $\mathrm{Cr}$ (III) and is more toxic than Cr(III) (Wang et al. 1997).

Among different species of marine bivalves, Wang (2001) has recently demonstrated that the difference in the uptake rate constants of metals is positively related to the filtration rate of the bivalves. The high rate of uptake from the dissolved phase by the slipper limpets was thus due, at least in part, to the high filtration rate of the animals, as a result of the welldeveloped gill filaments which integrate into a mesh covering the back of the mantle cavity (Ruppert \& Barnes 1994). The extended gill surface area may facilitate metal diffusion. In Crepidula onyx, the water current enters the mantle cavity from the right side of the body and exits from the left. Such a well developed structure may have facilitated the capture of phytoplankton and bacteria, although the efficiency of food capturing is somewhat higher for phytoplankton. The gill may retain a lower percentage of particles when feeding on bacteria-size particles, as is the case in the bivalves Mytilus edulis and Geukensia demissa (Jörgensen 1990). However, this study demonstrates that bacteria can be very efficiently retained by the limpets. The filtration rate for bacteria was only 1.3 to $1.9 \times$ lower than the filtration rate for phytoplankton particles.

Metal assimilation by Crepidula onyx followed a biphasic pattern, with a faster release rate within the first few hours and a slower release rate afterwards. The $A E$ s measured for $\mathrm{Cd}, \mathrm{Cr}$, and $\mathrm{Zn}$ from ingested phytoplankton were generally comparable to the AEs measured in other suspension feeding invertebrates (Wang \& Fisher 1999b). However, there was great variation in the metal AEs among different phytoplankton diets tested (Cd: 10 to $45 \%, \mathrm{Cr}: 10$ to $20 \%$, and Zn: 30 to $45 \%$ ). Previously, different mechanisms have been proposed to explain the variation of metal AEs observed among different metals and different diets, including metal distribution in the phytoplankton cytoplasm (Reinfelder \& Fisher 1991, Wang \& Fisher 1996), metal GPT across the digestive tract (Wang \& Fisher 1996, Chong \& Wang 2000), and the partitioning of digestive systems (Decho \& Luoma 1991, 1996). In this study, there was no clear trend to indicate that metal $A E$ was directly correlated with the metal distribution in the phytoplankton, presumably because only 4 algal diets were tested. When its distribution of metals in the bacteria is also considered, there appears to be a significant correlation between metal $A E$ and metal distribution in the cytoplasm for $\mathrm{Cr}$, whereas no significant correlation is evident for $\mathrm{Cd}$ and $\mathrm{Zn}$. There was also a significant correlation between the $A E$ of $\mathrm{Cr}$ and its GPT. These results suggest that both metal partition- 
ing in the diet and the animal's digestive processes are critical in $\mathrm{Cr}$ assimilation by the limpets.

The metal AEs measured from bacteria were somewhat comparable to the $A E$ s measured from phytoplankton for $\mathrm{Cd}$ and $\mathrm{Zn}$, whereas for $\mathrm{Cr}$ the $A E$ s from bacteria were much higher than the AEs from phytoplankton. The higher $A E$ of $\mathrm{Cr}$ from bacteria was due at least in part to its greater distribution in the bacterial cytoplasm and the longer GPT. Decho \& Luoma (1991, 1996) similarly found that the $A E \mathrm{~s}$ of $\mathrm{Cr}$ from bacteria were generally much higher than its $A E$ from phytoplankton ingested by the clams Potamorbula amurensis and Macoma balthica. For example, an $A E$ as high as $90 \%$ was found in the clams feeding on bacteria. They attributed such a high $A E$ to the efficient partitioning of $\mathrm{Cr}$ in the second phase of digestion, namely, the intracellular digestion, in which the digestive cells in the digestive diverticula phagocytized the cells. In Crepidula onyx, whether the digestive system was bi-phasic (e.g., extracellular and intracellular digestion) as observed in marine bivalves (Widdows et al. 1979) is unknown.

There are few studies quantifying the accumulation of metals by the marine bacteria. This study demonstrated that the accumulation of metals by the bacteria was controlled mainly by passive sorption. Following an initial sorption of metals onto the bacteria, there was little further increase in metal accumulation over the exposure time. The study quantified the dry weight concentration factors of metals over the $8 \mathrm{~h}$ exposure period. Because metals showed little accumulation following the initial sorption, the bioconcentration factor (assuming equilibrium conditions) was probably close to the concentration factor (which is a kinetic parameter) measured in this study. The measured concentration factor for bacteria was generally much greater than the bioconcentration factor measured for marine phytoplankton (Fisher \& Reinfelder 1995), largely due to the small size of bacteria, and thus the higher ratio of surface area to volume. However, metals may then be rapidly transported intracellularly by the bacteria, as reflected by the high percentage of metal distribution in the cytoplasm.

In the kinetic model employed in this study, the sources of metal accumulation in Crepidula onyx were broken down into the aqueous phase, bacteria, and phytoplankton. We assumed that metal uptake from each source was additive, i.e., metal uptake from 1 particulate source was independent of the influx from another source. Metal accumulation from the aqueous phase was quantified after exposing the animal to different metal concentrations. The influx of metals from bacteria and phytoplankton was further broken down into separate quantifiable parameters such as the metal's partition coefficient, filtration rate, and assimi- lation efficiency, each of which can be subjected to sensitive analysis to determine the most important parameter in the overall bioaccumulation.

Calculation using the kinetic model suggests that bacteria may be an important source for metal accumulation in the slipper limpet. Using the mean numeric value for each physiological and geochemical parameter, our model predicts that about 19 to $27 \%$ of dietary metals are indeed derived from ingested bacteria. Such an important contribution of metals from bacteria is primarily due to the high metal concentrations in the bacteria and the high assimilation of metals from ingested bacteria, despite the fact that the total biomass of bacteria was much lower than the natural seston. In addition, the slipper limpets have an efficient filtration system to retain the bacteria from the ambient water. These calculations considered only the freeliving bacteria. When the attached bacteria are also considered as a potential source for metal accumulation, it is likely that the contribution of bacteria as a source for metal accumulation may be much greater than this model predicts.

These calculations used the average bacterial abundance to calculate the ingestion by limpets of bacteria. In Hong Kong waters, bacterial abundance tends to be relatively high and stable $\left(1\right.$ to $3 \times 10^{6}$ cells $\mathrm{ml}^{-1}$, Gosselin \& Qian 1997) throughout most of the year. Similar bacteria concentrations have also been reported in other coastal areas (Rivkins et al. 1986, Douillet 1993). At the lowest bacterial concentration $\left(10^{6}\right.$ cells ml ${ }^{-1}$, Gosselin \& Qian 1997), the ingestion rate of bacteria by limpets is predicted to be $6 \mathrm{mg} \mathrm{g}^{-1}$ $\mathrm{d}^{-1}$, and the contribution of bacteria as source for metal accumulation will be about $13 \%$ for $\mathrm{Cd}, 16 \%$ for $\mathrm{Cr}$, and $11 \%$ for $\mathrm{Zn}$. At the upper level of bacterial abundance (e.g., $3 \times 10^{6}$ cells ml $^{-1}$ ), the contribution of bacterial metals would be 26 to $36 \%$ for the 3 metals considered in this study.

Several processes reflecting natural variability may complicate prediction of the quantitative importance of bacterial metals. This study used 2 bacterial strains originally isolated from Hong Kong coastal waters that are relatively large in size $(0.8$ to $1.2 \mu \mathrm{m})$. The calculated ingestion rate of bacteria based on measurements of the filtration rate and the dry weight of the 2 bacterial strains (M4 and M11) may have overestimated the actual ingestion rate under natural conditions. Both bacteria are free-living strains and in natural environments bacteria attached to algae or detritus may also be ingested by the limpets. These calculations assumed an average seston concentration of $1 \mathrm{mg} \mathrm{l}^{-1}$ to predict the relative importance of natural seston contributing to metal accumulation. The concentration of natural seston in Hong Kong, however, fluctuates with the seasons (Chiu et al. 1994). It is thus 
expected that the influx rate from the ingested phytoplankton can vary substantially under natural conditions. Furthermore, it is relatively well known that the concentration factors for metals in natural seston and bacteria are not single values and may vary greatly in a natural environment. Such variability can also substantially affect predictions of the exposure pathways of metals in the limpets.

The size of the food items used in this study ranged from 0.56 to $3750 \mu^{3}$ (calculated from data in Table 1). This size spectrum may cover bacteria, flagellates, protozoa, phytoplankton, small zooplankton, and detritus. Because the flagellates and protozoa graze on the bacteria (Fenchel 1987), metals associated with bacteria may be transferred to flagellates and protozoa (e.g., microbial loop) before they are finally transferred to the limpets. Despite the complicated picture in applying these modeling results to the real field situation, the study does indicate that bacteria are a potentially important source for metal accumulation by the limpets as a result of efficient filtering of bacteria and the high metal concentration in bacteria. With the emerging picture that filter feeders are able to capture bacteria in locations where these limpets are abundant, the role of bacteria in transferring metals should be assessed when predicting the source and fate of metals in coastal ecosystems.

Acknowledgements. We are grateful to Robert Dei and Lisa Soo for technical support, Bin Zhao for assistance with the phytoplankton and animal culture, Stanley Lau and Karen Mak for assistance with the bacterial cultures, and the 2 anonymous reviewers for their helpful comments. This study was supported by a subtask of the Pearl River Pollution Project (PREPP) to P.-Y.Q. and W.-X.W.

\section{LITERATURE CITED}

Azam F, Fenchel T, Field JG, Gray JS, Meyer-Reil LA, Thingstad F (1983) The ecological role of water-column microbes in the sea. Mar Ecol Prog Ser 10:257-263

Bak RPM, Joenje M, de Jong I, Lambrechts DYM, Nieuwland G (1998) Bacterial suspension feeding by coral reef benthic organisms. Mar Ecol Prog Ser 175:285-288

Barbeau K, Moffett JW, Caron DA, Croot PL, Erdner DL (1996) Role of protozoan grazing in relieving iron limitation of phytoplankton. Nature 380:61-64

Bjerregaard P, Topçuoğlu S, Fisher NS, Fowler SW (1985) Biokinetics of americium and plutonium in the mussel Mytilus edulis. Mar Ecol Prog Ser 21:99-111

Blackmore G (1998) An overview of trace metal pollution in the coastal waters of Hong Kong. Sci Total Environ 214: $21-48$

Chiu HMC, Hodgkiss IJ, Chan BSS (1994) Ecological studies of phytoplankton in Tai Tam Bay, Hong Kong. Hydrobiologia 273:81-94

Chong I, Wang WX (2000) Assimilation of Cd, Cr and Zn by the green mussel Perna viridis and the clam Ruditapes philippinarum. Environ Toxicol Chem 19:1660-1667
Decho AW, Luoma SN (1991) Time-courses in the retention of food material in the bivalves Potamocorula amurensis and Macoma balthica: significance of the absorption of carbon and chromium. Mar Ecol Prog Ser 78:303-314

Decho AW, Luoma SN (1996) Flexible digestion strategies and trace metal assimilation in marine bivales. Limnol Oceanogr 41:568-572

Douillet P (1993) Bacterivory in Pacific oyster Crassostrea gigas larvae. Mar Ecol Prog Ser 98:123-134

Douillet P, Langdon CJ (1993) Effects of marine bacteria on the culture of axenic oyster Crassostrea gigas (Thunberg) larvae. Biol Bull 184:36-51

Fenchel T (1987) Ecology-potential and limitations. In: Kinne $\mathrm{O}$ (ed) Excellence in ecology I. Ecology Institute, Oldendorf/Luhe, Germany

Fisher NS, Reinfelder JR (1995) Assimilation of metals in marine systems. In: Turner DR, Tessier A (eds) Metal speciation and bioavailability. Wiley \& Sons, New York, p 363-406

Fisher NS, Burns KS, Cherry RD, Heyraud M (1983) Accumulation and cellular distribution of ${ }^{241} \mathrm{Am},{ }^{210} \mathrm{Po}$, and ${ }^{210} \mathrm{~Pb}$ in two marine algae. Mar Ecol Prog Ser 11:233-237

George SG, Coombs TL (1977) The effects of chelating agents on the uptake and accumulation of cadmium by Mytilus edulis. Mar Biol 39:261-268

Gosselin LA, Qian PY (1997) Can bacterivory alone sustain larval development in the polychaete Hydroides elegans and the barnacle Balanus amphitrite? Mar Ecol Prog Ser 161:93-101

Gosselin LA, Qian PY (2000) Can bacterivory sustain survival and growth in early juveniles of the bryozoan Bugula neritina, the polychaete Hydroides elegans and the barnacle Balanus amphitrite? Mar Ecol Prog Ser 192:163-172

Guillard RRL (1975) Culture of phytoplankton for feeding marine invertebrate. In: Smith WL, Chanley MH (eds) Culture of marine invertebrate animals. Plenum Publishing, New York, p 29-60

Huang ZG, Morton B, Yipp YW (1984) The distribution and ecological features of Crepidula onyx in Hong Kong. Acta Oceanologica Sinica 5:827-839

Jörgensen CB (1990) Bivalve filter feeding: hydrodynamics, bioenergetics, physiology and ecology. Olsen \& Olsen, Fredenborg

Kreeger DA, Newell RIE (1996) Ingestion and assimilation of carbon from cellulolytic bacteria and heterotrophic flagellates by the mussels Geukensia demissa and Mytilus edulis (Bivalvia, Mollusca). Aquat Microb Ecol 11:205-214

Landrum PF, Lee IIH, Lydy MJ (1992) Toxicokinetics in aquatic systems: model comparisons and use in hazard assessment. Environ Toxicol Chem 11:1709-1715

Langdon CJ, Newell RIE (1990) Utilization of detritus and bacteria as food sources by two bivalve suspension-feeders, the oyster Crassostrea virginica and the mussel Geukensia demissa. Mar Ecol Prog Ser 58:299-310

Munger C, Hare L, Tessier A (1999) Cadmium sources and exchange rates for Chaoborus larvae in nature. Limnol Oceanogr 44:1763-1771

Pile AJ (1997) Finding Reiswig's missing carbon: quantification of sponge feeding using dual-beam flow cytometry. Proc 8th Int Coral Reef Symp 2:1403-1410

Porter KG, Feig YS (1980) The use of DAPI for identifying and counting aquatic microflora. Limnol Oceanogr 25:943-948

Reinfelder JR, Fisher NS (1991) The assimilation of elements ingested by marine copepods. Science 251:794-796

Reinfelder JR, Wang WX, Fisher NS (1998) Trace element trophic transfer in aquatic organisms: a critique of the kinetic model approach. Sci Total Environ 219:117-135 
Reiswig HM (1974) Water transport, respiration and energetics of three tropical marine sponges. J Exp Mar Biol Ecol 14:231-249

Rivkin RB, Bosch I, Pearse JS, Lessard EJ (1986) Bacterivory: a novel feeding mode for asteroid larvae. Science 233: 1311-1314

Roditi, HA, Fisher NS (1999) Rates and routes of trace element uptake in zebra mussels. Limnol Oceanogr 44:1730-1749

Ruppert EE, Barnes RD (1994) Invertebrate zoology, 6th edn. Saunders College Publishing, Fort Worth

Seiderer LJ, Newell RC (1985) Relative significance of phytoplankton, bacteria and plant detritus as carbon and nitrogen resources for the kelp bed filter-feeder Choromytilus meridionalis. Mar Ecol Prog Ser 22:127-139

Thomann RV (1981) Equilibrium model for fate of microcontaminants in diverse aquatic food chains. Can J Fish Aquat Sci 38:280-296

Twiss MR, Campbell PGC, Auclair JC (1996) Regeneration, recycling, and trophic transfer of trace metals by microbial food web organisms in the pelagic surface waters of Lake Erie. Limnol Oceanogr 41:1425-1437

Wang WX (2001) Comparison of trace metal uptake and absorption efficiency among marine bivalves. Environ Toxicol Chem 20:1367-1373

Wang WX, Dei RCH (1999a) Kinetic measurements of metal accumulation in two marine macroalgae. Mar Biol 135:

Editorial responsibility: James Hollibaugh,

Athens, Georgia, USA
$11-23$

Wang WX, Dei RCH (1999b) Factors affecting trace element uptake in the black mussel Septifer virgatus. Mar Ecol Prog Ser 186:161-172

Wang WX, Fisher NS (1996) Assimilation of trace elements and carbon by the mussel Mytilus edulis: effect of food composition. Limnol Oceanogr 41:197-207

Wang WX, Fisher NS (1999a) Delineating metal accumulation pathways for aquatic invertebrates. Sci Total Environ 237/238:459-472

Wang WX, Fisher NS (1999b) Assimilation efficiencies of chemical contaminants in aquatic invertebrates: a synthesis. Environ Toxicol Chem 18:2034-2045

Wang WX, Fisher NS, Luoma SN (1996) Kinetic determinations of trace elements bioacumulation in the mussels Mytilus edulis. Mar Ecol Prog Ser 140:91-113

Wang WX, Griscom SB, Fisher NS (1997) Bioavailability of $\mathrm{Cr}(\mathrm{III})$ and $\mathrm{Cr}(\mathrm{VI})$ to marine mussels from solute and particulate pathways. Environ Sci Technol 31:603-611

Widdows J (1985) Physiological procedure. In: Bayne BL, Brown DA, Bruns K, Dixon DR, Ivanovici A (eds) The effects of stress and pollution in marine animals. Praeger, New York, p 161-179.

Widdows J, Fieth P, Worrall CM (1979) Relationships between seston, available food and feeding activity in the common mussel Mytilus edulis. Mar Biol 50:195-207

Submitted: February 27, 2001; Accepted: July 4, 2001

Proofs received from author(s): August 16, 2001 